\title{
Teknik perbanyakan tanaman buah dan tanaman hias secara vegetatif untuk meningkatkan pendapatan masyarakat di era pandemi
}

\author{
Umi Fatmawati ${ }^{1 *}$, Harlita ${ }^{2}$, Meti Indrowati ${ }^{3}$, Dewi Puspita Sari ${ }^{4}$, Slamet \\ Santosa ${ }^{5}$ \\ 1 Universitas Sebelas Maret, Surakarta, Indonesia, email: umifatmawati@staff.uns.ac.id \\ 2Universitas Sebelas Maret, Surakarta, Indonesia, email: harlita@staff.uns.ac.id \\ 3Universitas Sebelas Maret, Surakarta, Indonesia email: metiindrowati@staff.uns.ac.id \\ ${ }^{4}$ Universitas Sebelas Maret, Surakarta, Indonesia email: dewipuspita@staff.uns.ac.id \\ 5 Universitas Sebelas Maret, Surakarta, Indonesia email: slametsantosa@staff.uns.ac.id \\ *Koresponden penulis
}

\section{Info Artikel}

Diajukan: 2021-10-26

Diterima: 2022-01-21

Diterbitkan: 2022-02-09

Keywords:

plant; propagation; vegetative; community; graffting; cutting

\section{Kata Kunci:}

tanaman; perbanyakan; vegetatif; masyarakat; cangkok; stek

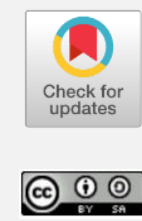

Lisensi: cc-by-sa

Copyright (c) 2022 Umi Fatmawati, Harlita, Meti Indrowati, Dewi Puspita Sari, Slamet Santosa

\begin{abstract}
Throughout the pandemic, public enthusiams in cultivating fruit and ornamental plants has increased. Along with developing hobbies, cultivating fruit and ornamental plants may help individuals boost their income by promoting their products. During the pandemic, the price per pot of fruit and decorative plants increased because to increasing market demand. The purpose of this activity is to transmit knowledge and skills in the vegetative cultivation of fruit and decorative plants, including cuttings, grafting, and shoot propagation, as well as to inform participants about business opportunities and marketing strategies for fruit and decorative plants in Mipitan Mojosongo Village, Surakarta. Socialization, workshops/training, and monitoring are all employed as strategies. Citrus, watery apple, star fruit, and mango are all examples of fruit trees that are grown vegetatively by grafting and cuttings. While ornamental plants grown vegetatively include aglaonema, euphorbia, and orchids, economically valuable plants propagated vegetatively include aglaonema, euphorbia, and orchids. According to the findings of this activity, more than $90 \%$ of participants reported that the plant propagation instruction provided them with advantages and information for nurturing fruit and decorative plants and turning them into economic opportunities.
\end{abstract}

Abstrak
Di masa pandemi saat ini, animo masyarakat mengenai budidaya
tanaman buah dan tanaman hias meningkat tajam. Selain untuk
menyalurkan hobi, budidaya tanaman buah dan tanaman hias juga
dapat meningkatkan pendapatan masyarakat dengan memasarkan
produk ke pasar. Harga per pot tanaman buah dan tanaman hias
melonjak di masa pandemi, dan juga permintaan pasar yang cukup
tinggi. Tujuan dari kegiatan ini adalah memberikan pengetahuan dan
keterampilan teknik budidaya tanaman buah dan tanaman hias secara
vegetatif seperti stek, cangkok, menyambung/grafting dan tunas
kepada mitra dan memberikan informasi mengenai prospek bisnis dan
strategi pemasaran tanaman buah dan tanaman hias di Kampung
Mipitan Mojosongo Surakarta. Selain itu juga dilakukan
pendampingan pemasaran produk tanaman hias dan tanaman buah
yang dikembangkan secara vegetatif. Metode yang dilakukan adalah
dengan sosialisasi, workshop/pelatihan, dan monitoring. Beberapa
jenis tanaman buah yang dikembangkan secara vegetatif adalah


tanaman jeruk, jambu air, belimbing dan mangga dengan cara cangkok dan stek. Sedangkan tanaman hias yang diperbanyak secara vegetatif adalah tanaman yang memiliki nilai ekonomi tinggi seperti aglaonema, euphorbia, dan anggrek. Hasil kegiatan ini sebanyak 90\% orang peserta menyatakan bahwa pelatihan perbanyakan tanaman memberi manfaat dan pengetahuan untuk membudidayakan tanaman buah dan hias serta mengembangkannya menjadi prospek wirausaha.

Cara mensitasi artikel:

Fatmawati, U., Harlita, Indrowati, M., Sari, D. P., \& Santosa, S. (2022). Teknik perbanyakan tanaman buah dan tanaman hias secara vegetatif untuk meningkatkan pendapatan masyarakat di era pandemi. Jurnal Inovasi Hasil Pengabdian Masyarakat (JIPEMAS), 5(1), 130-140. https://doi.org/10.33474/jipemas.v5i1.13726

\section{PENDAHULUAN}

Selama masa pandemi Covid-19, pemerintah dan tenaga kesehatan menganjurkan masyarakat untuk lebih banyak tinggal di rumah untuk mengurangi penyebaran dan infeksi virus Covid-19. Pembatasan aktivitas sosial ini sudah berlangsung hampir dua tahun, sehingga menimbulkan rasa bosan dan stress bagi masyarakat (Muslim, 2020). Aktivitas bercocok tanam merupakan salah satu upaya masyarakat untuk mengatasi hal tersebut. Animo masyarakat dalam kegiatan budidaya tanaman di rumah meningkat selama pandemi, sehingga jika harga tanaman hias dan tanaman buah melangit (Gunawan \& Sayaka, 2020). Selain mengatasi rasa bosan dan stress, aktivitas berkebun juga dapat meningkatkan kepedulian masyarakat terhadap lingkungan, menghasilkan udara bersih, serta berpartisipasi dalam mengatasi perubahan iklim. Aktivitas berkebun di pekarangan rumah juga berkontribusi dalam mengurangi emisi Gas Rumah Kaca (GRK) serta mengurangi sampah di lingkungan (Rosha et al., 2013).

Kampung Mipitan Kelurahan Mojosongo Kota Surakarta berlokasi di sebelah utara kampus Kentingan Universitas Sebelas Maret Surakarta. Kawasan kampung ini juga berdiri komplek kampus Institut Seni Indonesia (ISI) Surakarta, sehingga menjadikan kampung ini berkembang dan semakin banyak jumlah penduduknya karena banyak terdapat kos-kosan mahasiswa. Namun demikian, permasalahan yang dihadapi oleh warga di Kampung Mipitan adalah pendapatan warga berkurang signifikan selama pandemi Covid-19 dikarenakan sepinya usaha kos mahasiswa dan berdampak ke usaha lain seperti laundry, warung makan, dan jajanan kuliner juga mengalami penurunan omzet. Peluang untuk mengurangi dampak pandemi tersebut muncul dari warga. Adanya pekarangan warga yang cukup luas dan beberapa lahan juga masih belum dimanfaatkan, maka perlu pemberdayaan warga dalam memanfaatkan peluang tersebut misalnya dengan memanfaatkan pekarangan untuk budidaya tanaman produktif seperti tanaman buah, tanaman hias, maupun sayur-mayur. Namun kenyataannya, keterampilan dan pengetahuan warga mengenai budidaya tanaman buah dan tanaman hias masih rendah. Selain itu, kesiapan warga dalam menyambut program kampung iklim (Proklim) masih rendah dibandingkan dengan RW lain yang sudah menjadi percontohan misal di kampung Ngemplak Sutan Mojosongo. Proklim merupakan salah satu program berlingkup nasional bebasis pemberdayaan masyarakat di bidang lingkungan hidup yang dikembangkan oleh Kementrian Lingkungan Hidup (KLH) untuk 
mendorong partisipasi aktif dari masyarakat dan seluruh pihak yang terkait dalam melaksanakan aksi lokal ketahanan terhadap dampak perubahan iklim dan pengurangan emisi Gas Rumah Kaca (GRK) yang dilaksanakan minimal setingkat Dusun/RW/Dukuh dan maksimal tingkat kelurahan/desa (Furqan et al., 2020). Salah satu kegiatan yang dapat dilakukan untuk adaptasi dan mitigasi perubahan iklim adalah dengan melakukan peningkatan vegetasi tanaman sekaligus untuk peningkatan ketahanan pangan warga yaitu dengan budidaya pekarangan sekitar rumah dengan tanaman produktif seperti tanaman buah maupun tanaman hias (Faedlulloh et al., 2019).

Potensi sumber daya untuk pengembangan tanaman hias dan tanaman buah di kampung Mipitan Mojosongo antara lain lahan pekarangan yang dimiliki warga tergolong luas, banyak terdapat sisa sampah organik yang dapat dimanfaatkan menjadi pupuk, serta minat warga yang tinggi dalam berpartisipasi menjaga kelestarian lingkungan. Hal ini menjadi alasan utama tim pengabdian masyarakat menerapkan keterampilan dan teknologi budidaya tanaman buah dan tanaman hias secara vegetatif buatan. Budidaya tanaman buah yang berkualitas dapat memberikan manfaat selain untuk mencukupi kebutuhan sendiri, juga dapat menciptakan alternatif penghasilan keluarga. Namun tidak semua benih dan bibit tanaman memiliki kualitas yang baik, maka perlu dilakukan pemilihan bibit dan indukan tanaman yang bermutu untuk mendapatkan hasil yang baik dan kemudian dilakukan perbanyakan secara vegetatif buatan. Metode perbanyakan secara vegetatif buatan dipilih karena mudah dilakukan, dapat memperbanyak jenis-jenis tanaman yang sulit didapat, mendapatkan bibit unggul secara genetik, mempercepat pembuahan, serta menghindari terjadinya kekurangan benih karena tidak teraturnya masa pembungaan (Purnomosidhi et al., 2002).

Berdasarkan latar belakang tersebut, maka tim pengabdian masyarakat dari Universitas Sebelas Maret Surakarta bersama warga di kampung Mipitan Mojosongo Surakarta melaksanakan pelatihan dan workshop teknik perbanyakan tanaman buah dan tanaman hias secara vegetatif buatan. Kegiatan ini bertujuan untuk memberikan pengetahuan dan keterampilan kepada warga untuk membudidayakan tanaman buah dan tanaman hias yang berpotensi meningkatkan pendapatan masyarakat serta diharapkan warga dapat mengembangkan keterampilan yang diperoleh dalam budidaya tanaman untuk berwirausaha, mendukung ketahanan pangan, dan menjaga kelestarian lingkungan.

\section{METODE PELAKSANAAN}

Kegiatan pengabdian masyarakat dilaksanakan melalui workshop dan pelatihan mengenai teknik perbanyakan tanaman buah dan tanaman hias secara vegetatif buatan di kampung Mipitan kelurahan Mojosongo Kota Surakarta pada bulan Juni-Agustus 2021. Kegiatan ini diikuti oleh sebanyak 25 orang warga dari perwakilan kelompok tani dan Karang Taruna RW 36 Mipitan Mojosongo dengan memperhatikan protokol kesehatan yang ketat.

Tahapan kegiatan ini terdiri dari empat tahap yaitu: (1) tahap persiapan, (2) tahap sosialisasi budidaya tanaman buah dan tanaman hias secara 
vegetatif, (3) tahap pelatihan perbanyakan tanaman buah dan tanaman hias secara vegetatif, (4) tahap evaluasi. Tahap persiapan meliputi koordinasi jadwal pelaksanaan pelatihan dengan koordinator mitra yaitu Ketua RW 36 Bapak Widodo, serta persiapan alat dan bahan yang akan digunakan dalam pelatihan diantaranya: set alat grafting, pisau stek, gunting tanaman, media tanam berupa sekam bakar, cocopeat, akar pakis, pupuk kandang, pot, tanaman buah seperti jeruk nipis, belimbing, sawo manila, jambu air dan mangga. Untuk tanaman hias yang digunakan dalam praktek perbanyakan secara vegetatif buatan adalah aglonema, euphorbia, dan anggrek.

Tahap kedua adalah sosialisasi dan penyampaian materi mengenai perbanyakan tanaman buah dan tanaman hias secara vegetatif. Pada tahap ini juga disampaikan tentang bagaimana cara mencangkok, melakukan sambung pucuk dan stek batang. Materi dan praktek dipandu oleh Dr Slamet Santosa M.Si yang merupakan praktisi budidaya tanaman hias sekaligus juga anggota tim pengabdian. Pada tahap ini juga dilakukan survey mengenai pengetahuan awal warga terhadap teknik budidaya tanaman dan minat untuk mengikuti pelatihan teknik perbanyakan tanaman secara vegetatif buatan pada tanaman buah dan tanaman hias.

Tahap ketiga dari kegiatan ini adalah praktek teknik perbanyakan tanaman secara vegetatif buatan. Praktek dilakukan secara luring dan warga dibagi ke dalam dua kelompok, pembagian ini diharapkan seluruh peserta dapat berperan aktif dalam kegiatan praktek. Keterampilan yang dilatihkan yaitu mencangkok, pucuk sambung dan stek batang pada beberapa jenis tanaman buah dan tanaman hias. Tahap terakhir adalah evaluasi kegiatan dengan melakukan survey mengenai pengetahuan, manfaat dan saran pelaksanaan kegiatan dari peserta.

\section{HASIL DAN PEMBAHASAN}

\section{Survey dan analisis awal}

Survey dan analisis pengetahuan awal warga terhadap teknik perbanyakan tanaman secara vegetatif serta minat warga untuk mengikuti pelatihan perbanyakan dan budidaya tanaman buah dan tanaman hias dilakukan dengan membagikan kuesioner kepada warga. Data hasil survey awal disajikan pada Tabel 1. Survey dilakukan pada 25 orang warga Kampung Mipitan Kelurahan Mojosongo Kecamatan Jebres Kota Surakarta yang berpartisipasi dalam kegiatan pengabdian masyarakat.

Tabel 1. Hasil survey pengetahuan awal warga

\begin{tabular}{|c|c|c|c|c|}
\hline \multirow{2}{*}{ No } & \multirow{2}{*}{ Aspek } & \multirow{2}{*}{ Indikator } & \multicolumn{2}{|c|}{ Persentase (\%) } \\
\hline & & & Ya & Tidak \\
\hline \multirow[t]{2}{*}{1} & Pemanfaatan pekarangan & Memiliki pekarangan di sekitar rumah & 80 & 20 \\
\hline & rumah & $\begin{array}{l}\text { Memanfaatkan pekarangan rumah untuk } \\
\text { ditanami buah dan tanaman hias }\end{array}$ & 50 & 50 \\
\hline \multirow[t]{3}{*}{2} & Pengalaman melakukan & Pernah menjual produk tanaman budidaya & 12 & 88 \\
\hline & $\begin{array}{l}\text { perbanyakan tanaman } \\
\text { secara mandiri }\end{array}$ & $\begin{array}{l}\text { Pernah melakukan perbanyakan tanaman } \\
\text { secara vegetatif }\end{array}$ & 20 & 80 \\
\hline & & $\begin{array}{l}\text { Memiliki kesulitan dalam membudidayakan } \\
\text { tanaman }\end{array}$ & 40 & 60 \\
\hline
\end{tabular}

tanaman 


\begin{tabular}{|c|c|c|c|c|}
\hline \multirow{2}{*}{ No } & \multirow{2}{*}{ Aspek } & \multirow{2}{*}{ Indikator } & \multicolumn{2}{|c|}{ Persentase (\%) } \\
\hline & & & Ya & Tidak \\
\hline \multirow[t]{2}{*}{3} & $\begin{array}{l}\text { Minat untuk } \\
\text { mengembangkan tanaman } \\
\text { buah dan tanaman hias }\end{array}$ & $\begin{array}{l}\text { Tertarik mengikuti pelatihan perbanyakan } \\
\text { tanaman buah dan tanaman hias secara } \\
\text { vegetatif }\end{array}$ & 84 & 16 \\
\hline & secara vegetatif & $\begin{array}{l}\text { Tanaman buah dan tanaman hias memiliki } \\
\text { peluang usaha untuk dikembangkan } \\
\text { secara komersial }\end{array}$ & 90 & 10 \\
\hline
\end{tabular}

Berdasarkan hasil survey di atas diketahui bahwa sebagian besar responden $(80 \%)$ menyatakan memiliki pekarangan di sekitar rumah, dan $50 \%$ warga yang memanfaatkan pekarangan untuk budidaya tanaman hias dan tanaman buah-buahan. Sebanyak $20 \%$ responden menyatakan bahwa memiliki pengalaman membudidayakan tanaman buah secara vegetatif buatan, dan $40 \%$ responden menyatakan memiliki kesulitan dalam membudidayakan tanaman. Dari hasil survey juga diketahui bahwa sebagian besar responden menyatakan tertarik untuk mengikuti pelatihan perbanyakan tanaman buah dan tanaman hias secara vegetatif buatan dan tertarik untuk mengembangkan keterampilan yang dimiliki untuk wirausaha budidaya tanaman hias atau buah-buahan. Metode survey dipilih karena dapat mengungkapkan tingkat pengetahuan dan perilaku dari responden, sehingga hasil survey dapat menjadi bahan pertimbangan pengambilan kuputusan atau tindakan selanjutnya (Adiyanta, 2019).

2. Sosialisasi dan praktik perbanyakan tanaman buah dan tanaman hias Kegiatan berikutnya adalah sosialisasi dan praktek perbanyakan tanaman buah dan tanaman hias secara vegetatif buatan oleh mitra. Kegiatan ini dilaksanakan pada tanggal 22 Agustus 2021 secara luring dengan memperhatikan protokol kesehatan yang ketat. Kegiatan ini diikuti oleh sebanyak 25 orang peserta dari perwakilan anggota karang taruna dan kelompok tani RW 36 Mipitan Mojosongo Surakarta. Kegiatan ini terbagi menjadi dua sesi, yaitu sesi penyampaian materi dan sesi praktek. Sesi penyampaian materi oleh praktisi budidaya tanaman hias di Surakarta Dr Slamet Santosa M.Si (Gambar 1). Materi yang disampaikan berupa pengenalan macam-macam teknik perbanyakan vegetatif tanaman seperti mencangkok, pucuk sambung, dan stek batang serta faktor apa saja yang perlu diperhatikan agar perbanyakan tanaman secara vegetatif dapat berhasil dan menghasilkan anakan yang berkualitas. Tahap praktek dilakukan oleh warga dengan mempraktekkan bagaimana cara mencangkok, melakukan sambung pucuk, dan stek tanaman hias seperti pada tanaman aglaonema dan euphorbia. Pelaksanaan kegiatan pengabdian terlihat pada Gambar 2 dan Gambar 3. 


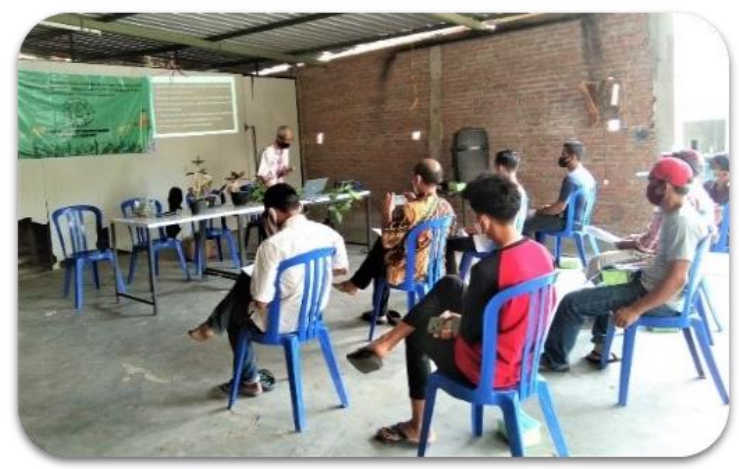

Gambar 1. Penyampaian materi mengenai teknik perbanyakan tanaman buah dan tanaman hias secara vegetatif buatan oleh narasumber (Dr Slamet Santosa, M.Si)

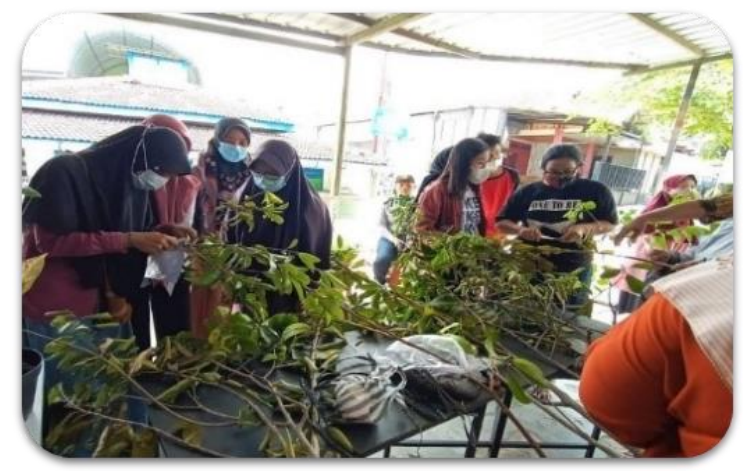

Gambar 2. Praktek mencangkok pada tanaman buah oleh warga

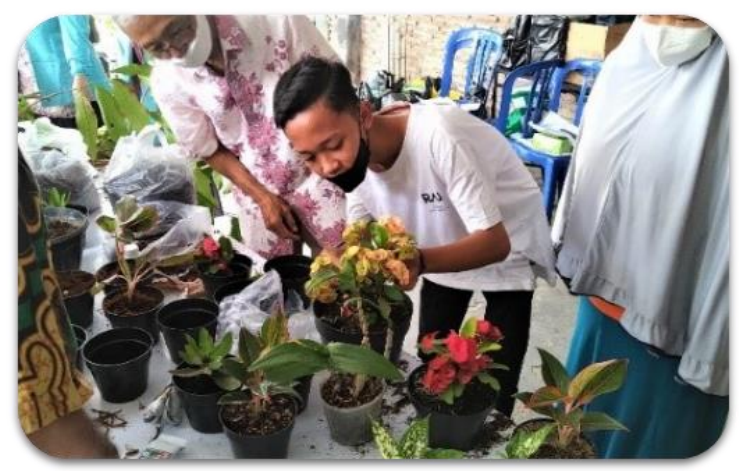

Gambar 3. Praktek stek batang pada tanaman Euphorbia

Praktek mencangkok dilakukan dengan memilih batang yang kokoh dan lurus yang sedang berbunga dan umur tidak terlalu tua dengan diameter batang kurang lebih $2 \mathrm{~cm}$ dan panjang $50 \mathrm{~cm}$. Kemudian dilakukan sayatan pada kulit ranting secara melingkar dengan menggunakan pisau sepanjang $3 \mathrm{~cm}$ dan pastikan kambium terkelupas agar tumbuh akar, kemudian tunggu sampai sayatan kering (Prameswari et al., 2014). Setelah kering, campuran media tanam yang berupa tanah, pupuk, cocopeat ditempelkan ke bagian ranting yang sudah dikupas 
kulitnya dan tutup dengan plastik bening dan ikat kedua ujungnya. Untuk memberikan akses udara dan air dapat masuk, maka plastik pembungkus di lubangi di beberapa bagian, dan dilakukan penyiraman setiap hari. Keberhasilan mencangkok dipengaruhi oleh banyak faktor antara lain umur dan ukuran batang, sifat media tanaman, suhu, kelembaban, air, dan ZPT (Hossel et al., 2017). Makin besar diameter batang, akar yang terbentuk juga lebih banyak, hal ini karena permukaan bidang perakaran yang lebih luas. Jenis tanaman yang banyak dikembangbiakkan dengan metode ini antara lain jeruk, apel, mangga dan Ficus spp. Metode cangkok paling sesuai diterapkan di lingkungan dengan kelembaban tinggi, namun juga bisa dilakukan di lingkungan kering namun dengan tetap menjaga kelembaban di sekitar area cangkok (Wiesman \& H. Jaenicke, 2002).

Perbanyakan tanaman sambung pucuk adalah perbanyakan dengan menggabungkan batang atas dan batang bawah. Batang bawah diharapkan menjadi batang yang tahan terhadap penyakit tanah dan kokoh, sedangkan batang atas merupakan bagian yang memiliki karakter produksi bagus sesuai yang diinginkan, misal buah manis, berukuran besar dan rimbun. Batang bawah yang digunakan biasanya menggunakan tanaman yang berasal dari biji sehingga memiliki perakaran yang kuat. Perpaduan dari bagian tanaman yang disatukan tersebut diharapkan akan menghasilkan tanaman jenis baru dengan sifat genetis yang memiliki keunggulan, yaitu kokoh, perakaran kuat, cepat berbuah, produktif, tahan penyakit dan kualitas buah baik sesuai dengan sifat genetis induknya. Teknik pucuk sambung dilakukan dengan membuat celah pada batang bawah dan dimasukkan batang atas (entres) yang memiliki paling tidak 3 mata tunas (Santoso \& Parwata, 2013). Pada kegiatan ini, praktek pucuk sambung dilakukan pada tanaman belimbing dan tanaman jambu air.

Perbanyakan tanaman hias secara vegetatif dilakukan pada tanaman aglaonema dan tanaman euphorbia yaitu dengan cara stek batang. Tanaman aglaonema dan euphorbia merupakan tanaman yang sedang naik daun di masa pandemi, harga per pot tanaman dapat mencapai ratusan ribu hingga jutaan rupiah. Perbanyakan ini diawali dengan memilih batang aglaonema yang sudah tua dan sehat, kemudian dilakukan pemotongan batang pada bagian bawah daun paling bawah (Piovano, 2009). Potongan bagian atas dapat langsung ditanam pada media tanam cocopeat yang dicampur dengan arang sekam dengan perbandingan $1: 2$, sedangkan potongan bawah dioles dengan fungisida untuk melindungi batang dari infeksi jamur patogen. Potongan ditanam pada media cocopeat secara horizontal dan diletakkan pada tempat yang teduh serta dilakukan penyiraman setiap hari. Cocopeat merupakan media tanam yang berasal dari sabut kelapa yang dihancurkan hingga berbentuk serat atau serbuk yang memiliki kemampuan menyerap air dan menggemburkan tanah (Shafira et al., 2021) sehingga tidak memerlukan banyak penyiraman dan mencegah batang menjadi busuk sebelum muncul akar. Campuran cocopeat dan arang sekam menjadikan media tanam untuk stek menjadi lebih gembur dan pori-pori media lebih banyak sehingga memungkinkan 
ujung akar untuk berkembang dan menghasilkan tunas baru (Mariana, 2017). Tunas baru akan muncul setelah kurang lebih 6 minggu. Gambar perbanyakan stek batang tanaman aglaonema tersaji pada Gambar 4.

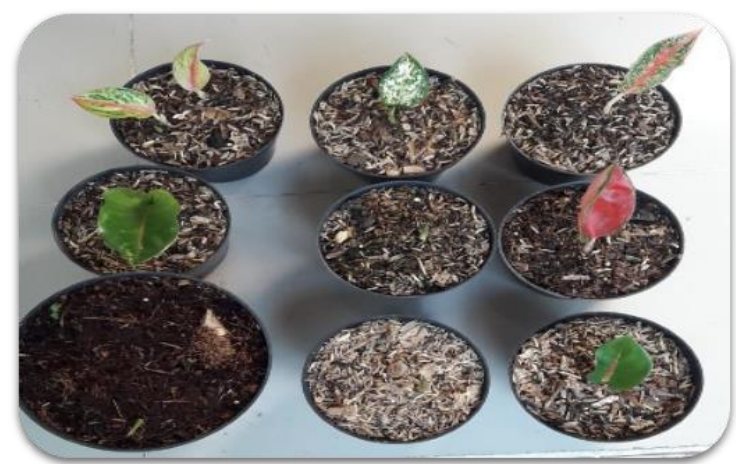

Gambar 4. Perbanyakan tanaman stek batang pada tanaman aglaonema bagian pucuk pada media tanam

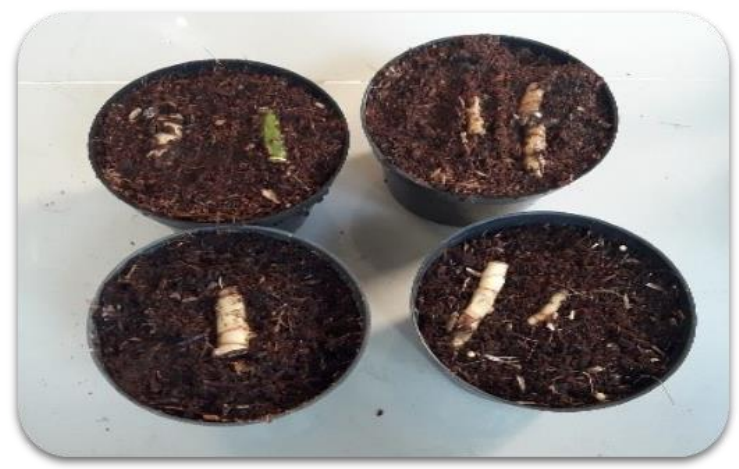

Gambar 5. Perbanyakan tanaman stek batang pada tanaman aglaonema bagian batang pada media cocopeat

Perbanyakan tanaman tanaman secara vegetatif buatan yang dilakukan pada kegiatan ini memiliki keuntungan yaitu menghasilkan jumlah bibit yang banyak dalam waktu yang relatif singkat dengan karakter sama dengan induknya, dapat memanfaatkan klon lokal sebagai sumber entres (tunas baru), selain itu juga dapat mencegah penyebaran hama dan penyakit dari satu tempat ke tempat lain, mudah dilakukan oleh petani atau pembudidaya dan keberhasilan cukup tinggi (Limbongan \& Djufry, 2013). Sehingga, dalam pelatihan ini, warga dapat dengan mudah mendapatkan bibit tanaman buah dan tanaman hias yang murah dan berkualitas dan dapat ditanam di lingkungan masing-masing.

\section{Evaluasi hasil kegiatan}

Tahap akhir kegiatan dilakukan monitoring dan evaluasi kegiatan dengan membagikan angket survey kepada warga yang telah berpartisipasi sebagai responden serta memberikan kesempatan untuk 
diskusi dan konsultasi antara warga dan praktisi mengenai permasalahan yang muncul dalam budidaya tanaman. Pembagian angket evaluasi bertujuan untuk mengetahui respon warga terhadap pelaksanaan kegiatan pelatihan perbanyakan tanaman buah dan tanaman hias secara vegetatif buatan serta minat warga untuk mengembangkan keterampilan yang diperoleh untuk pengembangan usaha. Hasil survey evaluasi kegiatan terdapat pada Tabel 2.

Tabel 2. Evaluasi kegiatan pengabdian masyarakat

\begin{tabular}{|c|c|c|c|c|}
\hline \multirow[b]{2}{*}{ No } & \multirow{2}{*}{ Aspek } & \multirow{2}{*}{ Indikator } & \multicolumn{2}{|c|}{ Persentase (\%) } \\
\hline & & & Ya & Tidak \\
\hline \multirow[t]{2}{*}{1.} & $\begin{array}{l}\text { Manfaat dari kegiatan } \\
\text { pengabdian }\end{array}$ & $\begin{array}{l}\text { Memberikan pengetahuan mengenai } \\
\text { budidaya tanaman secara vegetatif }\end{array}$ & 100 & 0 \\
\hline & & $\begin{array}{l}\text { Memberikan manfaat kepada Anda tentang } \\
\text { cara perbanyakan tanaman secara vegetatif }\end{array}$ & 92 & 8 \\
\hline \multirow[t]{3}{*}{2} & $\begin{array}{l}\text { Minat untuk } \\
\text { mengembangkan } \\
\text { perbanyakan vegetatif }\end{array}$ & $\begin{array}{l}\text { Ketertarikan warga untuk mempraktekkan } \\
\text { dan membudidayakan tanaman buah dan } \\
\text { hias secara vegetatif }\end{array}$ & 84 & 16 \\
\hline & $\begin{array}{l}\text { tanaman secara } \\
\text { mandiri }\end{array}$ & $\begin{array}{l}\text { Memungkinkan warga berwirausaha } \\
\text { mengembangkan budidaya tanaman buah } \\
\text { dan tanaman hias }\end{array}$ & 64 & 36 \\
\hline & & $\begin{array}{l}\text { Membudidayakan tanaman sendiri lebih } \\
\text { menguntungkan dibandingkan membeli di } \\
\text { kios/toko tanaman buah dan tanaman hias }\end{array}$ & 90 & 10 \\
\hline \multirow[t]{2}{*}{3.} & Evaluasi pelaksanaan & Kejelasan materi yang disampaikan & 100 & 0 \\
\hline & kegiatan & $\begin{array}{l}\text { Fasilitas dan peralatan yang digunakan } \\
\text { memadai }\end{array}$ & 100 & 0 \\
\hline
\end{tabular}

Berdasarkan hasil survey evaluasi kegiatan menunjukkan hasil lebih dari $92 \%$ warga menyatakan bahwa kegiatan pelatihan yang telah dilaksanakan memberikan manfaat pengetahuan dan teknis mengenai perbanyakan tanaman vegetatif buatan. Sebanyak $64 \%$ warga menyatakan tertarik untuk mengembangkan keterampilan yang diperoleh untuk berwirausaha pengembangan budidaya tanaman buah dan tanaman hias. Seluruh responden juga menyatakan bahwa materi yang disampaikan dalam pelatihan ini sangat jelas serta fasilitas dan peralatan yang digunakan dalam pelatihan ini cukup memadahi.

Pengetahuan dan keterampilan yang diperoleh warga melalui kegiatan workshop teknik budidaya tanaman buah dan tanaman hias secara vegetatif buatan ini diharapkan dapat dikembangkan budidaya tanaman buah dan tanaman hias di sekitar lingkungan tempat tinggal masing-masing. Pengembangan budidaya tanaman selain berpotensi sebagai wirausaha untuk meningkatkan pendapatan warga juga dapat menjadi upaya meningkatkan ketahanan pangan dan penghijauan lingkungan dalam rangka mitigasi perubahan iklim (Syahrin et al., 2020).

\section{KESIMPULAN}

Hasil survey pengetahuan awal warga menunjukkan bahwa sebagian besar responden $(80 \%)$ menyatakan memiliki pekarangan di sekitar rumah, namun baru $50 \%$ warga yang memanfaatkan pekarangan dengan tanaman produktif, dan $40 \%$ responden juga menyatakan memiliki kesulitan dalam 
membudidayakan tanaman, sehingga sebagian besar warga menyatakan tertarik untuk mengikuti pelatihan perbanyakan tanaman buah dan tanaman hias secara vegetatif buatan. Hasil survey awal menjadi bahan pengambilan keputusan untuk menyelenggaran kegiatan pengabdian masyarakat mengenai perbanyakan tanaman buah dan tanaman hias secara vegetatif buatan.

Berdasarkan hasil pelaksanaan kegiatan pengabdian di masyarakat, dapat disimpulkan bahwa kegiatan pelatihan praktek perbanyakan tanaman buah dan tanaman hias secara vegetatif dilaksanakan dalam 2 sesi yaitu sesi penyampaian materi dan sesi praktek dan diikuti oleh 25 orang peserta di kampung Mipitan Mojosongo Surakarta. Seluruh peserta antusias mengikuti kegiatan pelatihan. Jenis tanaman hias yang dikembangkan secara stek batang antara lain: aglaonema, euphorbia, dan anggrek. Sedangkan jenis tanaman buah yang dikembangkan secara cangkok dan sambung pucuk diantaranya: jeruk lemon, belimbing, jambu air, sawo manila. Setelah dilakukan kegiatan sosialisasi dan praktek sebagian besar warga > 90\% menyatakan bahwa kegiatan pelatihan memberikan pengetahuan dan manfaat mengenai cara perbanyakan vegetatif tanaman.

Kegiatan ini perlu dilakukan pelatihan pada warga mengenai keterampilan pembuatan pupuk hayati dan formulasi media tanam yang optimal untuk mendukung keberhasilan budidaya tanaman buah dan tanaman hias. Selain itu, perlu dilakukan pelatihan mengenai strategi pengembangan bisnis tanaman meliputi manajemen bisnis, akses pasar, dan akses modal agar warga dapat mengembangkan keterampilan yang diperoleh untuk menciptakan wirausaha baru di bidang tanaman buah dan tanaman hias.

\section{UCAPAN TERIMAKASIH}

Ucapan terima kasih kami sampaikan kepada LPPM Universitas Sebelas Maret Surakarta atas pendanaan kegiatan ini melalui Skim Pengabdian Kepada Masyarakat Hibah Grup Riset (PKM-HGR) Universitas Sebelas Maret Surakarta dana non-APBN tahun anggaran 2021 kepada Dr Umi Fatmawati M.Si dengan no kontrak 261/UN27.22/HK.07.00/2021.

\section{DAFTAR RUJUKAN}

Adiyanta, F. C. S. (2019). Hukum dan Studi Penelitian Empiris: Penggunaan Metode Survey sebagai Instrumen Penelitian Hukum Empiris. Administrative Law and Governance Journal, 2(4), 697-709. https://doi.org/10.14710/alj.v2i4.697-709

Faedlulloh, D., Irawan, B., \& Prasetyanti, R. (2019). Program unggulan kampung iklim (proklim) berbasis pemberdayaan masyarakat. Publisia: Jurnal IImu Administrasi Publik, 4(1), 28-44. https://doi.org/10.26905/pjiap.v4i1.2364

Furqan, M. H., Aziz, D., \& Wahyuni, R. (2020). Implementasi Program Kampung Iklim (ProKlim) di Gampong Lambung Kecamatan Meuraxa Kota Banda Aceh. Jurnal Pendidikan Geosfer, 5(2), 42-49. https://doi.org/10.23701/jpg.v5i2.21691

Gunawan, E., \& Sayaka, B. (2020). Imbas Pandemi Covid-19, Bisnis Tanaman 
Hias Naik Daun. Pusat Sosial Ekonomi Dan Kebijakan Pertanian Kementrian Pertanian.

Hossel, C., Júnior, A. W., De Oliveira Hossel, J. S. A., Fabiane, K. C., \& Citadin, I. (2017). "Cerejeira da mata" and "guabijuzeiro" propagation by air layering. Comunicata Scientiae, 8(4), 581-586. https://doi.org/10.14295/CS.v8i4.2194

Limbongan, J., \& Djufry, F. (2013). Pengembangan Teknologi Sambung Pucuk Sebagai Alternatif Pilihan Perbanyakan Bibit Kakao. J. Litbang Pert, 32(4), 166-172. https://doi.org/10.21082/jp3.v32n4.2013.p166-172

Mariana, M. (2017). Pengaruh Media Tanam Terhadap Pertumbuhan Stek Batang Nilam. Agrica Ekstensia, 11(1), 1-8.

Muslim, M. (2020). Manajemen Stress pada Masa Pandemi Covid-19. ESENSI: Jurnal Manajemen Bisnis, 23(2), 192-201. https://ibn.ejournal.id/index.php/ESENSI/article/view/205

Piovano, S. (2009). Propagation by Cuttings, Layering and Division Publications and Educational Resources / Virginia Tech. January 2009.

Prameswari, Z. K., Trisnowati, S., \& Waluyo, S. (2014). The Influence of Rooting Media and Hormone Substance on Layering of Sapodilla (Manilkara zapota (L.) van Royen) in Wet Season. Vegetalika, 3(4), 107-118. https://doi.org/10.22146/veg.5766

Purnomosidhi, P., Suparman, Roshetko, J. M., \& Mulawarman. (2002).

Perbanyakan dan Budidaya Tanaman Buah-Buahan Dengan penakanan pada durian, mangga, jeruk, melinjo dan sawo. International Centre for Research in Agroforestry Southeast Asia Regional Research Programme.

Rosha, P. T., Fitriyana, M. N., Ulfa, S. F., \& Dharminto. (2013). Pemanfaatan

Sansevieria Tanaman Hias Penyerap Polutan Sebagai Upaya Mengurangi Pencemaran Udara Di Kota Semarang. Jurnal Ilmiah Mahasiswa, 3(1), 1-6. https://ejournal.undip.ac.id/index.php/jim/article/view/10863

Santoso, B. B., \& Parwata, I. A. (2013). Grafting Teknik Memperbaiki Produktivitas Tanaman Jarak Pagar (Jatropha curcas). Universitas Mataram.

Shafira, W., Akbar, A. A., \& Saziati, O. (2021). Penggunaan Cocopeat Sebagai Pengganti Topsoil Dalam Upaya Perbaikan Kualitas Lingkungan di Lahan Pascatambang di Desa Toba, Kabupaten Sanggau. Jurnal IImu Lingkungan, 19(2), 432-443. https://doi.org/10.14710/jil.19.2.432-443

Syahrin, M. A., Syaharuddin, S., \& Rahman, A. M. (2020). Environmental Awareness of Kampung Hijau Society, Sungai Bilu Banjarmasin. The Kalimantan Social Studies Journal, 1(2), 191-200. https://doi.org/10.20527/kss.v1i2.2042

Wiesman, Z., \& H. Jaenicke. (2002). Vegetative tree propagation in agroforestry. Concepts and Principles. Training Guidelines and References. International Centre for Research in Agroforestry, Nairobi, Kenya, 1-15. 